

\section{Chris Marker}

\section{MANCHESTER 1824}

Manchester University Press 
FRENCH FILM DiRECTORS

DIANA HOLMES and ROBERT INGRAM series editors

DUDLEY ANDREW series consultant

Auterism from Assayas to Ozon: five directors KATE INCE

Jean-Jacques Beineix PHIL POWRIE

Luc Besson SUSAN HAYWARD

Bertrand Blier SUE HARRIS

Robert Bresson KEITH READER

Leos Carax GARIN DOWD AND FERGUS DALEY

Claude Chabrol GUY AUSTIN

Henri-Georges Clouzot CHRISTOPHER LLOYD

Jean Cocteau JAMES WILLIAMS

Claire Denis MARTINE BEUGNET

Marguerite Duras RENATE GÜNTHER

Georges Franju KATE INCE

Jean-Luc Godard DOUGLAS MORREY

Mathieu Kassovitz WILL HIGBEE

Diane Kurys CARRIE TARR

Patrice Leconte LISA DOWNING

Louis Malle HUGO FREY

Georges Méliès ELIZABETH EZRA

François Ozon ANDREW ASIBONG

Maurice Pialat MARJA WAREHIME

Jean Renoir MARTIN O'SHAUGHNESSY

Alain Resnais EMMA WILSON

Eric Rohmer DEREK SCHILLING

Coline Serreau BRIGITTE ROLLET

André Téchiné BILL MARSHALL

François Truffaut DIANA HOLMES AND ROBERT INGRAM

Agnès Varda ALISON SMITH

Jean Vigo MICHAEL TEMPLE 
FRENCH Film DiRECTORS

\section{Chris Marker}

\section{SARAH COOPER}

Manchester University Press

MANCHESTER 


\section{Copyright (C) Sarah Cooper 2008}

The right of Sarah Cooper to be identified as the author of this work has been asserted by her in accordance with the Copyright, Designs and Patents Act 1988.

Published by Manchester University Press Altrincham Street, Manchester M1 7JA, UK

www.manchesteruniversitypress.co.uk

British Library Cataloguing-in-Publication Data A catalogue record for this book is available from the British Library Library of Congress Cataloging-in-Publication Data applied for ISBN 978 o 719074455 hardback

First published 2008

$17161514131211100908 \quad 10987654321$

Typeset in Scala with Meta display

by Koinonia, Manchester 